\title{
Assessment of Environmental Effect on Fertility Restoration in Sweet Pepper (Capsicum annum L. var. grossum)
}

\author{
Manoj Kumar Nalla ${ }^{1 *}$, V.K. Sharma ${ }^{1}$, Manisha Mangal ${ }^{1}$, Arpita Srivastava ${ }^{1}$, \\ R.S. Raje $^{2}$, S.S. Dey ${ }^{3}$ and Chandresh Chandel ${ }^{3}$ \\ ${ }^{1}$ Division of Vegetable science, ICAR-Indian Agricultural Research Institute, \\ New Delhi 110 012, India \\ ${ }^{2}$ Division of Genetics, ICAR-Indian Agricultural Research Institute, New Delhi 110 012, India \\ ${ }^{3}$ ICAR-IARI Regional station, Katrain, H.P-175129, India \\ *Corresponding author
}

\begin{tabular}{|c|c|}
\hline & A B S T R A C T \\
\hline & \multirow{6}{*}{$\begin{array}{l}\text { In pepper, cytoplasmic male sterility trait is important for cost effective hybrid seed } \\
\text { production which helps in commercial hybridization without manual emasculation and } \\
\text { pollination. Commercial use of CMS hybrid necessitates stable performance of sterile and } \\
\text { fertile to promise genetically consistent } \text { F }_{1} \text { seed production and reduced the risk of } \\
\text { incomplete fertility. Therefore, the present study was carried out to explore the fertility } \\
\text { restoration of } 20 \text { CMS based sweet pepper (Capsicum annum L. var. grossum) hybrids a } \\
\text { two different locations IARI, Regional Station, Katrain, Himachal Pradesh, and IARI, New } \\
\text { Delhi. The trials were performed in a randomized block design with three replications. In } \\
\text { each environment, plants were assessed for pollen viability, pollen germination and } \\
\text { number of seeds per fruit. Among the hybrids tested KTCA3 X KTCR1, KTCA3 X } \\
\text { KTCR4, KTCA3 x KTCR5, KTCA5 X KTCR1, KTCA5 X KTCR5, KTCA5 X KTCR6 } \\
\text { KTCA5 X KTCR9 and KTCA5 X KTCR10 showed same fertility status estimated basec } \\
\text { on mean values and were stable in both the locations. There is substantial variation among } \\
\text { hybrids over the locations for pollen fertility. Among hybrids, KTCA5 x KTCR5 and } \\
\text { KTCA5 x KTCR9 showed stable and good performance at both the locations. Since the } \\
\text { mean performance of number of seeds is better in location } 1 \text { than in location } 2 \text {, hence it } \\
\text { suggests that location } 1 \text { is preferable for seed production. The pooled analysis data } \\
\text { revealed a significant (P } \leq 0.001 \text { ) genotypes } x \text { environment interactions for all the traits. In } \\
\text { the present study, we observed that the fertility restoration of hybrids was dependent no } \\
\text { only on the genetic makeup of the plant but also influenced by the environment conditions } \\
\text { of the plants grown. Moreover, our results provide a comprehensive overview for our } \\
\text { understanding of the environment effect on the function of fertility restoration genes and to } \\
\text { develop stable restorer line for hybrid breeding. }\end{array}$} \\
\hline Keywords & \\
\hline $\begin{array}{l}\text { Fertility restoration, } \\
\text { G x E interaction, } \\
\text { Stability, Pooled } \\
\text { mean analysis. }\end{array}$ & \\
\hline Article Info & \\
\hline $\begin{array}{l}\text { Accepted: } \\
\text { 07 October } 2017 \\
\text { Available Online: } \\
10 \text { December } 2017\end{array}$ & \\
\hline & \\
\hline
\end{tabular}

\section{Introduction}

In Capsicum annum L. both pungent and nonpungent types are prevalent and have a commercial importance among the five domesticated capsicum species (Kumar and
Rai, 2005; Bosland and Votava, 2000). Bell pepper (Capsicum annum L. var. grossum) which is commonly known as sweet pepper or shimla mirch or capsicum is one of the highly remunerative vegetable crop grown in India. 
Because of its economical grandness as a very high value vegetable crop both in domestic and overseas food market due to more consumer preferences and its utilisation in many culinary products the need of capsicum is the need of the day at the present situation. Although a majority of Indian farmers cultivate locally adapted cultivars, recently hybrids are becoming very popular (Kalloo et al., 2001). $\mathrm{F}_{1}$ hybrids cultivars are widely used in pepper production because of its significant heterosis for many economical traits (Guo et al., 1981). The area under pepper hybrid production in India has increased from $2.4 \%$ in 1997-1998 to about 25\% at present. It is estimated that the hybrids take up $80 \%$ of the total seeds used in pepper production. Hybrid seeds production at present mainly relies on laborious manual emasculation and pollination. In contrast, seed purity cannot be assured and the price is hardly affordable. Hybrid seed production relying on male sterility could lower the cost by reducing time and labour needed for preparing female flowers. Similarly, the use of male sterility could also increase the genetic purity of the $F_{1}$ seeds by preventing self-pollination. About 4-5\% of hybrid seeds sale of private seeds companies are with cytoplasmic male sterility (CMS) (Schreinemachers et al., 2016) and it is expected that use of male sterility system in pepper would facilitate to reduce the cost of producing hybrids seeds by $40 \%$ (Lin et al., 2015).

The practical importance of the CMS system in breeding is highly dependent on the presence of a restorer of fertility (Rf) gene and stable response in various environments (Yoo, 1990; Hanson and Bentola, 2004). Peterson (1958) and Shifriss (1997) both had reported that the expression of the male-sterility gene could be affected by prevalent environmental condition (Shifriss and Guri, 1979). Partial sterility of pollen, which may be affected by the environment or controlled by other specific genes, was first reported by Zhang et al., (2000). Wang et al., (2006) had also observed that sterility and fertility could be modified to a large extent by environment fluctuations, especially temperature. Shifrisss, (1997) had reported that CMS pepper lines frequently display unstable, sterility under low temperatures. Commercial use of CMS requires high stable fertility restoration to assure high F1 hybrid seed production.
Thus, changes in temperature may lead to alterations in fertility ranging from complete sterility to partial fertility, which may also lead to CMS lines self-crossing or be crossed as the male parent (Guylas et al., 2006). In pepper, complete sterility and high fertility depend on genes which may differ in distinct maintainer and restorer lines, and whose expression is environmentdependent. Therefore, the application of the CMS line is based on the understanding of the genetic characteristics of the CMS line and the relationship between maintaining and restoring of male sterility.

In cytoplasmic male sterility-based (CMS) hybrid seed production, the stability of fertility restoration across a wide range of environments is one of the major bottlenecks. Therefore, the present study was carried out to investigate the stability of fertility restoration at two different locations IARI regional station, Katrain (Location1) and IARI, New Delhi (Location 2).

The main objective of this research was to know the stability for fertility restoration and to assess the effect of environment on the fertility restoration in the hybrids. Therefore, the present investigation was conducted to study the stability of twenty hybrids along with a check for male fertility restoration under different environmental conditions.

\section{Materials and Methods}

The experimental materials consist of 20 hybrids and a standard check variety Mighty of sweet pepper which were developed at from IARI, Regional Station, Katrain (H.P).

Two CMS lines KTCA 3 and KTCA5 were crossed with ten lines (as testers in Line $\mathrm{x}$ Tester fashion, that resulted in 20 hybrid combinations, which were evaluated at Katrain, Himachal Pradesh $\left(32.10^{\circ} \mathrm{N}, 77.124^{\circ} \mathrm{E}, 1688 \mathrm{MSL}\right)$ from March to October, 2016 and IARI, New Delhi, $\left(28.63^{\circ} \mathrm{N}, 77.15^{\circ}\right.$ E $\left.228 \mathrm{MSL}\right)$ during June to December, 2016 to study their stability of fertility restoration under different environmental conditions.

A randomized complete block design was used in 
field trials with three replications and planted at $45 \times 45 \mathrm{~cm}$ spacing. Every five selected plant of a hybrid in each replication was tested for pollen fertility/sterility status which is a significant character to study fertility restoration in $F_{1}$ hybrids. The observations were recorded on pollen viability and germination at the initial flowering stage and seed number per fruit in ripened fruit.

\section{Analysis of pollen viability}

In the present study, fertility of pollen grains was identified by using $2 \%$ acetocarmine solution. Five well-developed flower buds were collected randomly from different plants at the time of anthesis (9-10 a.m.). From each bud, anthers were crushed on a glass slide and stained with a drop of $2 \%$ acetocarmine and examined under a compound microscope using a $10 \mathrm{X}$ magnification lens. The round and well-stained pollen grains were regarded as fertile, whereas shriveled, hyaline, and unstained pollen grains were scored as sterile. The proportion of fertile and sterile pollen grains was expressed in percentage.

Pollen viability $(\%)=($ Number of stained pollen grains / total pollen grains) $\mathrm{x} 100$. The plants showing $>80 \%$ pollen fertility were considered fully male-fertile and those with 50\%- 79\%, $10 \%-49 \%$, and $<10 \%$ pollen fertility were respectively considered as partially male fertile, partially male sterile, and completely male sterile plants.

\section{Analysis of pollen germination}

Germination of pollen was done on a liquid media. Five flower buds were collected and shade dried. Pollen grains isolated from flowers were germinated in vitro on culture medium with a composition of $0.01 \%$ boric acid $+10 \%$ sucrose The slides on which pollens were germinated were kept in a shaker for $2-3 \mathrm{hrs}$ at $25^{\circ} \mathrm{C}$ in the dark. For each experiment, germinated and nongerminated pollen grains were observed under a compound microscope. The pollen germination rate was calculated in accordance with the following formula:

Pollen Germination $(\%)=($ Number of germinated pollen grains / total pollen grains) x 100 (Ye et al., 2010).
To determine the number of seeds per fruit mature ripens fruits were harvested, parthenocarpic fruits were discarded and a number of seeds in each fruit were calculated (Liu and Gniffke, 2004).

\section{Data analysis}

Pooled analysis of variance (ANOVA) was carried out using the mixed procedure of the SAS software version 9.3 for Windows (SAS Institute Inc. 2011, Cary, NC). Stability of fertility restoration in hybrids and expression of male fertility in hybrid lines were determined using genotype $(\mathrm{G})+$ genotype $\times$ environment $(\mathrm{GE})$ interaction. Applying the above stated materials and methods the following results obtained were explained.

\section{Results and Discussion}

The fertility restorations studies reveal that the genotypes variance of hybrids under study were highly significant $(\mathrm{P}>0.001)$ for pollen viability $(\%)$, Seed germination $(\%)$ and number of seeds per fruit. This indicates the presence of substantial variation among the hybrids under study in both locations (Table 1). The mean values of both the locations were subjected to pooled mean analysis that showed significant genetic variation among the hybrids for all the traits. The mean square values to $G \times E$ interaction were highly significant for all the traits which show that the hybrids were performing differently over the range of environments.

\section{Mean Performance}

The fertility restoration studies in CMS lines helps in understanding the seed set of hybrids. The pollen fertility is an important trait to study fertility restoration in hybrids (Chaudhari et al., 2015). The pollen fertility of hybrid represents the restoring ability of pollen parent when crossed with the male sterile line. The mean performance of pollen fertility traits of each hybrid at both locations and their pooled mean were shown in (Table 1). Based on mean performance, the pollen fertility was ranged from $95.67 \%$ to $51.60 \%$ across the locations. 
Table.1 Means of the traits recorded across the environmental sites

\begin{tabular}{|c|c|c|c|c|c|c|c|c|c|c|c|c|}
\hline & \multirow[t]{2}{*}{ Genotype } & \multicolumn{3}{|c|}{ Viability (\%) } & \multicolumn{3}{|c|}{ Germination (\%) } & \multicolumn{2}{|c|}{ Seed number } & \multirow[b]{2}{*}{$\begin{array}{l}\text { Pooled } \\
\text { mean }\end{array}$} & \multicolumn{2}{|c|}{$\begin{array}{l}\text { Fertility status based on } \\
\text { mean }\end{array}$} \\
\hline & & $\begin{array}{l}\text { Locaton } \\
1\end{array}$ & $\begin{array}{l}\text { Locaton } \\
2\end{array}$ & $\begin{array}{l}\text { pooled } \\
\text { mean }\end{array}$ & $\begin{array}{l}\text { Locaton } \\
1\end{array}$ & \begin{tabular}{|l} 
Locaton \\
2
\end{tabular} & $\begin{array}{l}\text { Pooled } \\
\text { mean }\end{array}$ & $\begin{array}{l}\text { Locaton } \\
1\end{array}$ & $\begin{array}{l}\text { Locaton } \\
2\end{array}$ & & $\begin{array}{l}\text { Environment } \\
1\end{array}$ & $\begin{array}{l}\text { Environment } \\
2\end{array}$ \\
\hline 1. & KTCA3X KTCR1 & 85.17 & 84.00 & 84.58 & 81.67 & 78.5 & 80.08 & 128.80 & 88.60 & 108.7 & Fertile & Fertile \\
\hline 2. & KTCA3X KTCR2 & 87.67 & 77.67 & 82.67 & 89.20 & 70.33 & 79.76 & 119.67 & 70.50 & 95.08 & Fertile & Par.Fertile \\
\hline 3. & KTCA3X KTCR3 & 85.83 & 73.67 & 79.75 & 81.50 & 53.60 & 67.55 & 116.50 & 48.00 & 82.25 & Fertile & Par.Sertile \\
\hline 4. & KTCA3X KTCR4 & 88.33 & 78.17 & 83.25 & 83.60 & 79.83 & 81.71 & 120.00 & 91.00 & 105.5 & Fertile & Fertile \\
\hline 5. & KTCA3X KTCR5 & 85.67 & 81.67 & 83.67 & 80.50 & 74.83 & 77.66 & 104.17 & 93.50 & 98.83 & Fertile & Fertile \\
\hline 6. & KTCA3X KTCR6 & 69.17 & 79.83 & 74.5 & 63.35 & 59.50 & 61.42 & 77.67 & 63.50 & 70.58 & Par. fertile & Par.Fertile \\
\hline 7. & KTCA3X KTCR7 & 80.70 & 83.80 & 82.25 & 82.20 & 81.00 & 81.60 & 110.83 & 89.80 & 100.31 & Fertile & Fertile \\
\hline 8. & KTCA3X KTCR8 & 80.20 & 86.00 & 83.1 & 68.17 & 66.33 & 67.25 & 71.80 & 65.00 & 68.4 & Par.Fertile & Par. Fertile \\
\hline 9. & KTCA3X KTCR9 & 84.67 & 80.60 & 82.33 & 74.17 & 74.17 & 74.17 & 96.50 & 85.67 & 91.08 & Fertile & Par. Fertile \\
\hline 10. & KTCA3X KTCR10 & 87.00 & 79.67 & 83.33 & 80.33 & 67.00 & 73.66 & 103.50 & 66.68 & 85.09 & Fertile & Par. Fertile \\
\hline 11. & KTCA5XKTCR1 & 86.83 & 80.50 & 83.66 & 82.17 & 78.83 & 80.50 & 106.80 & 112.0 & 109.4 & Fertile & Fertile \\
\hline 12. & KTCA5X KTCR2 & 92.00 & 76.50 & 84.25 & 81.50 & 56.70 & 69.10 & 100.75 & 51.00 & 75.87 & Fertile & Par. Sterile \\
\hline 13. & KTCA5X KTCR3 & 82.83 & 79.50 & 81.16 & 79.50 & 71.80 & 75.65 & 95.75 & 83.33 & 89.54 & Fertile & Par. Fertile \\
\hline 14. & KTCA5X KTCR4 & 89.33 & 76.50 & 82.91 & 79.83 & 66.83 & 73.33 & 97.75 & 72.17 & 84.96 & Fertile & Par. Fertile \\
\hline 15. & KTCA5X KTCR5 & 87.17 & 83.33 & 85.25 & 80.20 & 83.20 & 81.70 & 115.25 & 104.0 & 109.62 & Fertile & Fertile \\
\hline 16. & KTCA5X KTCR6 & 85.50 & 73.00 & 79.25 & 82.00 & 63.33 & 72.66 & 98.75 & 74.83 & 86.79 & Fertile & Par. Fertile \\
\hline 17. & KTCA5X KTCR7 & 80.50 & 66.40 & 73.45 & 68.83 & 67.00 & 67.91 & 65.75 & 74.50 & 70.12 & Par. Fertile & Par. Fertile \\
\hline 18. & KTCA5X KTCR8 & 84.83 & 72.17 & 78.5 & 74.17 & 51.50 & 62.83 & 71.50 & 32.00 & 51.75 & Par. Fertile & Par. sterile \\
\hline 19. & KTCA5X KTCR9 & 91.00 & 79.33 & 85.16 & 82.17 & 66.83 & 74.50 & 98.75 & 79.67 & 89.21 & Fertile & Fertile \\
\hline 20. & KTCA5X KTCR10 & 84.67 & 82.00 & 83.33 & 81.60 & 77.80 & 79.70 & 97.75 & 96.33 & 97.04 & Fertile & Fertile \\
\hline 21. & Check & 97.20 & 92.82 & 95.01 & 94.00 & 83.17 & 88.58 & 152.67 & 131.33 & 142.0 & Fertile & Fertile \\
\hline 22. & Mean & 85.13 & 79.78 & 84.58 & 79.30 & 70.62 & 74.96 & 101.57 & 79.50 & -- & -- & -- \\
\hline 23. & GenotypicVariance $\left(\sigma^{2} g\right)$ & $17.54 * *$ & $13.08 * *$ & -- & $39.31 * *$ & $50.45^{* *}$ & -- & $\begin{array}{l}180.16^{*} \\
*\end{array}$ & $\begin{array}{l}260.89 * \\
*\end{array}$ & -- & -- & - \\
\hline 24. & Phenotypic Variance $\left(\sigma^{2} p\right)$ & 35.01 & 19.45 & -- & 47.81 & 66.12 & -- & 293.79 & 335.79 & -- & -- & -- \\
\hline 25 & $\mathrm{CV}(\%)$ & 2.80 & 4.75 & -- & 2.32 & 3.56 & -- & 9.64 & 7.18 & -- & -- & -- \\
\hline 26 & LSD at $1 \%$ & 5.2573 & 8.3697 & -- & 4.0619 & 5.5509 & -- & 21.611 & 12.601 & -- & -- & -- \\
\hline
\end{tabular}


Table.2 Mean square combined analysis for viability, seed germination, seed no for site 1 and site 2

\begin{tabular}{|c|c|c|c|c|c|c|c|c|c|c|c|}
\hline & & & \multicolumn{3}{|l|}{ Mss } & \multicolumn{3}{|l|}{ Fvalue } & \multicolumn{3}{|c|}{ Significance } \\
\hline & & Df & Viability & Germination & $\begin{array}{l}\text { Seed } \\
\text { no. }\end{array}$ & Viability & Germination & $\begin{array}{l}\text { Seed } \\
\text { no. }\end{array}$ & Viability & Germination & $\begin{array}{l}\text { Seed } \\
\text { no. }\end{array}$ \\
\hline \multirow[t]{2}{*}{ Replication } & Location 1 & 2 & 14.55 & 10.07 & 41.46 & 0.29 & 0.0623 & 0.626 & Ns & Ns & Ns \\
\hline & Location 2 & 2 & 18.0 & 9.36 & 15.43 & 1.25 & 1.48 & 0.47 & & & \\
\hline \multirow[t]{2}{*}{ Genotype } & Location1 & 20 & 99.78 & 147.78 & 1148.42 & 17.60 & 43.67 & 11.98 & $* *$ & $* *$ & $* *$ \\
\hline & Location 2 & 20 & 56.26 & 203.54 & 1381.33 & 3.91 & 32.21 & 42.42 & $* *$ & $* *$ & $* *$ \\
\hline \multirow[t]{2}{*}{ Error } & Location 1 & 40 & 5.66 & 3.38 & 95.78 & \multirow[t]{2}{*}{--} & \multirow[t]{2}{*}{--} & \multirow[t]{2}{*}{--} & \multirow[t]{2}{*}{---} & \multirow[t]{2}{*}{--} & \multirow[t]{2}{*}{--} \\
\hline & Location 2 & 40 & 14.36 & 6.31 & 32.56 & & & & & & \\
\hline \multirow[t]{2}{*}{ Total } & Location 1 & 62 & -- & -- & -- & \multirow[t]{2}{*}{-- } & \multirow[t]{2}{*}{-- } & \multirow[t]{2}{*}{--} & \multirow[t]{2}{*}{---} & \multirow[t]{2}{*}{--} & \multirow[t]{2}{*}{-- } \\
\hline & Location 2 & 62 & -- & -- & -- & & & & & & \\
\hline
\end{tabular}

Table.3 Line x Tester pooled anova

\begin{tabular}{|c|c|c|c|c|c|c|c|}
\hline & df & VIABILITY & & GERMINATION & & SEED NUMBER & \\
\hline Replicates & 2.00 & 11.75 & & 17.26 & $*$ & 54.40 & \\
\hline Environments & 1.00 & 869.41 & $* * *$ & 2205.92 & $* * *$ & 14660.04 & $* * *$ \\
\hline Rep * Env. & 2.00 & 19.46 & & 4.57 & & 17.42 & \\
\hline Crosses & 19.00 & 41.21 & $* * *$ & 210.62 & $* * *$ & 1245.89 & $* * *$ \\
\hline Line effect & 1.00 & 14.70 & & 1.75 & & 578.38 & \\
\hline Tester effect & 9.00 & 72.40 & $* *$ & 277.48 & & 1765.85 & \\
\hline Line $*$ Tester effect & 9.00 & 12.96 & & 166.96 & $* * *$ & 800.10 & $* * *$ \\
\hline Env * Crosses & 19.00 & 84.40 & $* * *$ & 97.29 & $* * *$ & 538.75 & $* * *$ \\
\hline Env $*$ Line effect & 1.00 & 273.01 & & 59.50 & & 489.45 & \\
\hline Env $*$ Tester effect & 9.00 & 68.91 & & 96.42 & & 559.89 & \\
\hline Env $* \mathrm{~L} * \mathrm{~T}$ effect & 9.00 & 78.93 & $* * *$ & 102.35 & $* * *$ & 523.08 & $* * *$ \\
\hline Error & 76.00 & 10.46 & & 5.02 & & 62.98 & \\
\hline Total & 119.00 & 34.57 & & 71.27 & & 449.57 & \\
\hline
\end{tabular}

Fig.I 1 and 2 Depict high fertile pollen, 3 nad 4 depicts partially fertile pollen and 5 and 6 depict partially sterile pollen images under a 10x compound microscope.
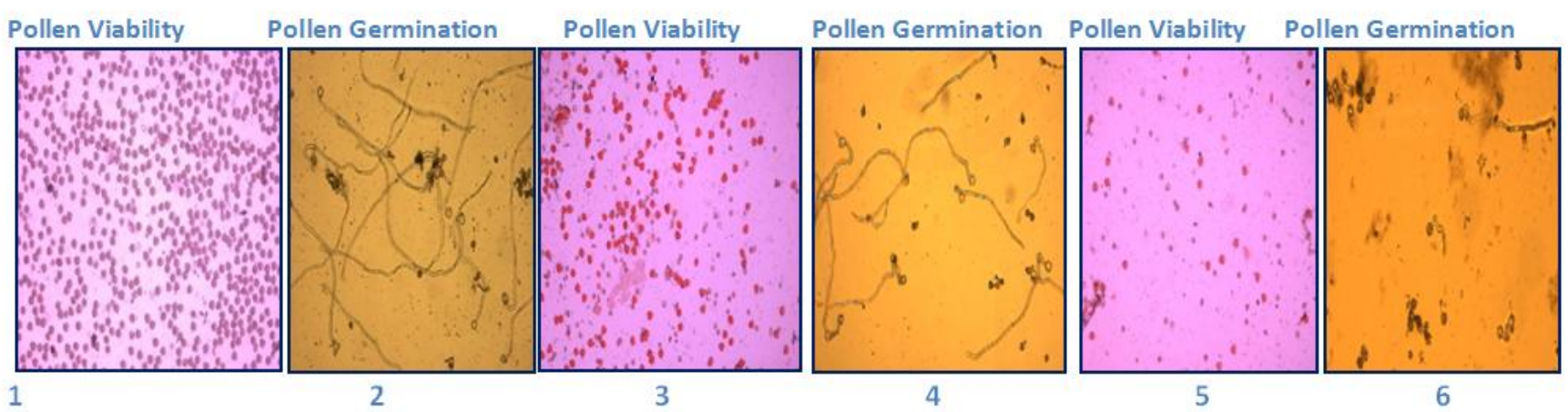
Fig.1I Comparision of mean values of pollen viability, pollen germination and seed number of hybrids under Katrain and New Delhi location

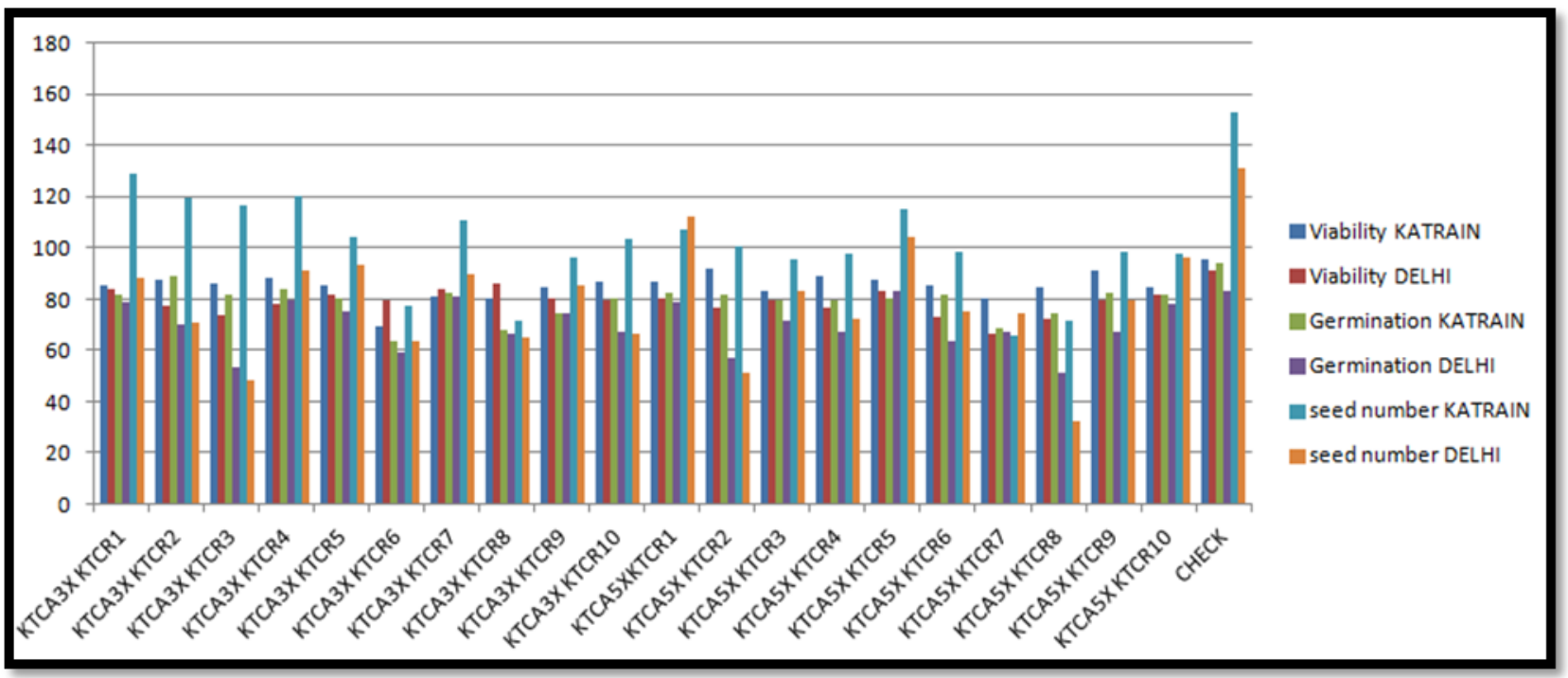

Similar results were also reported by Ali et al., 2014 in rice crop. Higher the pollen fertility implies high fertility restoration and vice-versa. Among hybrids, in Location 1, the highest mean value for pollen viability was shown by KTCA $5 \mathrm{x}$ KTCR2 $(92 \%)$ followed by KTCA5 x KTCR9 $(91 \%)$ and check variety showed the highest mean value of $97.2 \%$ among all the genotypes in both locations. Whereas, in the location 2 highest mean value was observed by hybrid KTCA3 x KTCR8 $(86 \%)$ followed by KTCA3 x KTCR1 $(84 \%)$ and KTCA3 x KTCR7 (83.8\%). The mean value of check variety for pollen fertility at location 2 is 92.82\%. KTCA5 x KTCA7 (66.4\%), KTCA3 x KTCA6 (69.1\%) and KTCA3 x KTCA3 (73.6\%) had shown low values for pollen viability. Furthermore, the hybrids are KTCA3 x KTCR1, KTCA3 x KTCR5, KTCA5 $x$ KTCR1 and KTCA5X KTCR5, shown high viability more than $80 \%$ pollen performance at both the locations. The hybrids, KTCA5 x KTCR2, KTCA5 x KTCR9 and KTCA5 x KTCR4 showed high pollen viability in location 1 , whereas the CMS line KTCA3 when crossed with KTCR1, KTCR7, and KTCR8 showed markedly high restoration in location 2. Tembhurne and Rao (2012) had also reported many hybrid combinations with good stable fertility restoration in chilli genoypes.

Furthermore, at Location 1 the maximum mean value for germination rate is shown by KTCA3 $\mathrm{x}$ KTCR2 (89.2\%) followed by KTCA3 x KTCR4 $(84 \%)$. The pollen germination ranged from $89.20 \%$ to $51.5 \%$ in the hybrids. Likewise in Location 2, the maximum mean value is showed by KTCA5 x KTCR5 (83.2\%) and is followed by KTCA3 x KTCR7 (81\%). The lowest value observed in KTCA5 $x$ KTCR8 $(51.5 \%)$ and KTCA5 $x$ KTCR2 (56.7\%) in location 2. Comparatively, the pollen germination and pollen viability values of location 1 are higher than that of location 2 which reveals that at the Location 1 environmental conditions were better for pollen fertility. This variation may be due to the pollen fertility restoring genes differ in their penetrance or expressivity differed with genotypes or with the environment or due to the existence of modifier genes (Srijan et al., 2015).

In addition, the mean value for a maximum of seed per fruit is obtained from hybrids at Location 1 by KTCA3 x KTCR1 (128) and KTCA3 x KTCR2 (120) and for check variety (153). Besides in location 2, the maximum seeds were obtained in hybrid KTCA5 x KTCR1 (112) followed by KTCA5 x KTCR5 (104) and for check variety (132). The seed number varied in a range of 32 to 152.6. The average number of seeds per fruit in Location 1 is more that the location 2, which shows that the Katrain location is preferable for seed production. In support of the 
present findings, Terry (2000) had reported that lower temperature conditions are suitable for hybrid seed production in capsicum but high day and night above $35^{\circ} \mathrm{C}$ and $21^{\circ} \mathrm{C}$ respectively were not congenial. Among the CMS lines, average production of seeds per fruit was higher with KTCA3 than KTCA5 line. This suggests that CMS line KTCA3 is preferable for seed production. Among the hybrids tested KTCA3 x KTCR1, KTCA3 x KTCR4, KTCA3 x KTCR5, KTCA3 x KTCR7, KTCA5 x KTCR1, KTCA5 x KTCR5, KTCA5 $x$ KTCR9 and KTCA $x$ KTCR10 are showing the same fertility status with high value of fertility, which is estimated based on mean value performance over both locations whereas the KTCA3 x KTCR2, KTCA3 $\mathrm{x}$ KTCR3, KTCA3 $\mathrm{x}$ KTCR9, KTCA3 $\mathrm{x}$ KTCR10, KTCA5 x KTCR2, KTCA5 x KTCR3, KTCA5 x KTCR6 and KTCA5 x KTCR8 hybrids had shown differences in fertility status at both the locations.

\section{Genotypic variance and $\mathbf{G} \times \mathbf{E}$ interaction}

The pollen viability (\%), germination (\%), and number of seeds per fruit had shown highly significant $(\mathrm{P} \leq 0.01)$ genotypic differences among hybrids for all the characters under study. It indicates that there is substantial variation among hybrids for pollen fertility. The mean genotypic values from the two different locations were subjected to pooled analysis that revealed the mean square attributable to GxE interaction was significantly high at $(\mathrm{P} \leq 0.001)$ for all the traits. In this study, the GxE interaction is explained not only by the nature of the trait but also because of environments are different, in ANOVA combined analysis environmental effects were the main contributors to the sum of total square. Therefore, testing in other locations would allow a better understanding of such interaction, interpreting results accurately without any negative interference on the results under the study.

The pooled analysis revealed a highly significant genotypes $\mathrm{x}$ environment interactions for pollen viability, pollen germination and a number of seeds for fruit. The above result indicates that the genotypes were performing differently over a range of environments. Therefore, we can infer that there is a significant effect of environment on fertility restoration of male fertile line on sterile line. Chaudhari et al., (2015) also reported that there is environment effect on fertility restoration of hybrids in the case of pigeon pea crop.

From the current study, we conclude that there is a significant effect of environment on the stability of fertility restoration. In comparison, the hybrids performances in Katrain location were better than that of in the New Delhi location in terms of traits like pollen viability, pollen germination, and a number of seeds for fruit. Similarly, the Katrain location is best for high and stable expression of fertility. In case of seed production, the Katrain location is preferable because of good seed set assurance. Thus, use of these studies can substantially increase the probability of identifying stable restorers from diverse genetic sources. From this study by developing high stable restorer lines in pepper, it has a great scope in future as it is expected to open commercial exploitation of CMS hybrid technology in sweet pepper.

\section{References}

Ali M, Hossain M A, Hasan M J and Kabir M E. 2014. Identification of maintainer and restorer lines in local aromatic rice (Oryza sativa). Bangladesh Journal of Agricultural Research 39(1): 1-12.

B.V. Tembhurne and S.K. Rao., 2012. Identification of fertility restorer and sterility maintainer lines in chilli (Capsicum annuum L.) Journal of Spices and Aromatic Crops, 21 (1): 68-70.

Bosland, P.W., and Votava, E J., 2000. Peppers: Vegetable and spice capsicums [M]. Wallingford, CABI Publishing, pp.13-38.

Chaudhari, S., A. N. Tikle., Uttamchand, K. B., Saxena and Rathore, A., 2015. Stability of Cytoplasmic Genetic Male Sterility and Fertility Restoration in Pigeonpea. Jour. of Crop Improvement, 29:269-280.

Gulyas, G., Pakozdik, K., Lee, J.S. and Hirata.Y., 2006. Analysis of fertility restoration by using cytoplasmic male-sterile red pepper (Capsicum annuum 1.) lines. Breed. Sci. 56: 331-334. 
Guo, S., Shen, H.L., Yang, W.C., Yang, J and Wang, W. 2009. Isolation of fertility restoration-related ESTs in pepper cytoplasmic male sterility lines using SSH. Acta Horticulturae Sinica, 36, 1443-1449.

Hanson, M.R. and Bentolila, S., 2004. Interactions of mitochondrial and nuclear genes that affect male gametophyte development. Plant Cell, 16(Suppl): S154-S169.

Kalloo, G., Banerjee, M.K., Kumar, S., Prakash, C., 2001. Hybrid vegetable technology in India: an overview. In: Kalloo, G., Singh, K. (Eds.), Emerging Scenario of Vegetable Research and Development. Research Periodicals and Book Publishing House, New Delhi, pp. 104-117.

Kumar, S. and Rai, M., 2005. Chile in India. Chile Pepper Institute Newsletter (XXII), pp. 1-3

Lin, S., W., H. C. Shieh., Y. W. Wang., C. W. Tan., R. Schafleitne.r, W. J. Yang, and S. Kumar., 2015: Restorer breeding in sweet pepper: introgressing $\mathrm{Rf}$ allele from hot pepper through marker-assisted backcrossing. Sci. Hortic. 197, 170-175.

Liu W.Y. and Gniffke. P. A., 2004 stability of AVRDC cytoplasmic male sterile pepper lines grown under low temperature. Capsicum and Eggplant news letter, 23: 8588.

Peterson, P.A., 1958. Cytoplasmically inherited male sterile in Capsicum. J. American Naturalist, 92(863): 111-119.

Schreinemachers, Chandra Rao K. P., Easdown W., Hanson, P and Kumar, S., 2017. The contribution of International vegetable breeding to private seed companies in India. Genet. Resour. Crop Evol, 4:1037-1049.

Shifriss, C. and Guri, A., 1979. Variation in stability of cytoplasmic male sterility in $C$. annuum L. J Amer. Soc Hort Sci 104:9496.

Shifriss, C., 1997. Male sterility in pepper (Capsicum annuum L.). Euphytica, 93, 8388.

Srijan, A, Sudheer Kumar., S, Damodar Raju., Ch and Jagadeeshwar, R., 2015. Studies for the Identification of Good Restorers and Maintainers in Rice (Oryza sativa L.) Research Journal of Agricultural Sciences 6(4): 751-753.

Terry G. Berke., 2000. Hybrid Seed Production in Capsicum, Journal of New Seeds, 1: 3-4, 49-67.

Wang, Z., Zou, Y., Li, X., Zhang, Q., Chen, L., Wu, H., Su, D., Chen, Y., Guo, J, Luo, D., Long. Y., Zhong, Y. and Liua, Y., 2006. Cytoplasmic male sterility of rice with Boro II cytoplasm is caused by a cytotoxic peptide and is restored by two related PPR motif genes via distinct codes of mRNA silencing. Plant Cell, 18:676-687.

Ye, ZW, Du, J.H., Su, M.S. and Li, L.L., 2010. Cluster analysis for the quantity and germinating characteristics of the pollens from 92 peach cultivars. Acta. Hortic. Sci. 37: 525-531.

Yoo, I.W., 1990. The inheritance of male sterility and its utilization for breeding in pepper (Capsicum spp.). Dissertation, Kyung Hee University.

Zhang, B.X., Huang, S.W., Yang, G.M., Guo, J.Z., 2000. Two RAPD markers linked to a major fertility restorer gene in pepper. Euphytica, 113, 155-161.

\section{How to cite this article:}

Manoj Kumar Nalla, V.K. Sharma, Manisha Mangal, Arpita Srivastava, R.S. Raje, S.S. Dey and Chandresh Chandel. 2017. Assessment of Environmental Effect on Fertility Restoration in Sweet Pepper (Capsicum annum L. var. grossum). Int.J.Curr.Microbiol.App.Sci. 6(12): 870877. doi: https://doi.org/10.20546/ijcmas.2017.612.094 